\title{
立位と座位での前傾角度の違いが静的な 屈曲弛緩現象へ及ぼす影響
}

\author{
Effects of Trunk Angle in the Sitting and Standing Postures \\ on the Static Flexion Relaxation Phenomenon
}

隈元 庸夫 $^{1)}$ 世古 俊明 ${ }^{2)}$ 田中 昌史 ${ }^{2)}$ 伊藤 俊一 ${ }^{2)}$

\footnotetext{
Tsuneo KUMAMOTO, PhD, RPT ${ }^{1)}$, TOSHIAKI SEKO, RPT ${ }^{2)}$, MASASHI TANAKA, MS, RPT ${ }^{2)}$, ToshIKAZU ITO, PhD, RPT $^{2)}$

1) Department of Physical Therapy, School of Health and Social Services, Saitama Prefectural University: 820 Sannomiya, Koshigaya-shi, Saitama 343-8540, Japan.TEL+81 48-973-4181E-mail: kumamoto-tsuneo@spu.ac.jp

${ }^{2)}$ Hokkaido Institute of Rehabilitation Technology, in the City of Chitose
}

Rigakuryoho Kagaku 30(2): 279-283, 2015. Submitted Oct. 31, 2014. Accepted Dec. 10, 2014.

\begin{abstract}
Purpose] The effects of different postures on the static flexion relaxation phenomenon were compared using electromyography, to clarify whether the angles for the activation and relaxation of the spinal muscles are different. [Subjects and Methods] Thirty healthy males maintained several different trunk inclination angles while standing and sitting. The muscle activities were measured and compared among the different postures and the different trunk angles: 0, 10, 20, 30, 40, 50, 60, and maximum forward leaning. The thoracic and lumbar erector spinae, multifidus, gluteus maximus, and biceps femoris were the target muscles. [Results] Muscle activities increased with increasing forward inclination angle, but at low inclination angles in the sitting position, the activities of the multifidus and erector spinae were constant. Between the postures, trunk muscle activities became significantly lower in the sitting position than in the standing position with increasing inclination. [Conclusion] Compared to standing, muscle activities at low inclination angles have low, constant values.
\end{abstract}

Key words: flexion relaxation phenomenon, low back pain, muscle activity

要旨：〔目的〕姿勢の違いが静的な屈曲弛緩現象へ及ぼす影響を筋電図学的に比較し，背筋群を弛緩，賦活すべき角 度が異なるかを明確化すること。〔対象と方法〕健常男性 30 名において多段階な体幹前傾位保持の運動を立位と座 位で実施した。前傾角度 $\left(0,10 ， 20 ， 30 ， 40 ， 50,60^{\circ}\right.$, 最大前傾位) の違いと体位の違いに拈ける筋活動量を比 較検討した，胸・腰部脊柱起立筋，多裂筋，大殿筋，大腿二頭筋を導出筋とした。〔結果〕前傾角度別では前傾位ほ ど筋活動量が増加したが，座位では浅い前傾位保持の段階で多裂筋を含めた脊柱起立筋群の筋活動量が一定となった。 体位別では座位で前傾位となるほど体幹筋活動量は立位時よりも有意に低值となった。〔結語〕立位と比較して, 座 位では浅い前傾位の段階で背筋群の筋活動量が低值で一定となる。

キーワード : 屈曲弛緩現象, 腰痛, 筋活動

\footnotetext{
1) 埼玉県立大学 保健医療福祉学部 理学療法学科: 埼玉県越谷市三野宮 820番地 ( ₹ 343-8540) TEL 048-973-4181

2) 北海道千歳リハビリテーション学院

受付日 2014 年 10 月 31 日 受理日 2014 年 12 月 10 日
} 


\section{I.はじめに}

厚生労働省が報告した平成 22 年国民生活基礎調査 1$)$ における「世帯員の健康状況」の「自覚症状の状況」の 結果を症状別にみると, 男性では腰痛, 女性では肩こり に次いで腰痛の有訴者率が人口千人に対して 89.1 人, 117.6 人と高く, 腰痛対策は重大な社会的問題となって いる．また，超高齢社会となった今日ではいわゆる老老 介護の視点から介護時の作業性腰痛症も問題視されてい る 2). 特に介護においては体幹を屈曲させた前傾姿勢が 1 日の作業姿勢の 3 割を占めることから, 介護時の作業 性腰痛症には姿勢の影響が大きいと考えられる ${ }^{3)}$.

前傾姿勢での腰痛の原因の一つを解明しうる知見とし て屈曲弛緩現象（flexion relaxation phenomenon; 以下， FRP）がある．FRP とは立位から体幹を屈曲した際に， 健常者では腰部背筋群の筋活動が消失する現象であり, その存在は従来から広く知られてきた ${ }^{4)}$. FRP の発生機 序は伸張反射が抑制されたものであり4)，背筋群の遠心 性収縮による姿勢保持から勒帯など軟部組織などによる 受動的な姿勢保持機構への移行の結果とされる5). いわ ゆる腰痛症とされる非特異的腰痛症患者においては最大 屈曲位でも腰部背筋群の過剩収縮が生じており, FRP の出現頻度が低かったとする報告が多数みられるように なった 6,7)。 そのためFRPの消失の結果が腰痛増悪と悪 化に関与していると考えられ7), その感度が $88.8 \%$, 特 異度が $81.3 \%$ と共に高いことから, 腰痛の客観的な治 療効果判定の指標になりうるものとして改めて注目され ている 8,9).

近年, 欧米では屈曲弛緩比率 (flexion relaxation phenomenon ratio; 以下, FRR) として, 直立位 (upright) の筋活動量を脱力位 (slump) の筋活動量で除した安静 時 FRR や, 体幹屈曲時と体幹伸展時の筋活動量をそれ ぞれ最大屈曲位での筋活動量で除した運動時 FRRを用 いて腰痛症に対するリハビリの効果を筋電図学的に検討 した報告が散見されるようになった10,11)。しかし，腰 痛の訴えは立位時だけではなく座位時のことも多く，立 位と座位で痛みが異なる症例も多くみられる。そのため, これまでに我々は立位と座位での FRP の出現率の比較 検討を健常者における基礎的研究として行った結果, FRPの出現率は立位で高く，座位で低かった ${ }^{12)}$ 。また, 腰痛は動的状況だけではなく姿勢保持状況での訴えも多 (8).

本研究の目的は，立位と座位でのFRPを，静的に体 幹屈曲保持中の屈曲角度の違いで健常者を対象として比 較検討し, 背筋群を弛緩すべき角度, 逆に背筋群の筋活 動を賦活させ脊柱安定化すべき角度, この両者が立位と 座位で異なるかを明確化することである。

\section{II. 対象と方法}

\section{1. 対象}

本研究は事前に埼玉県立大学倫理委員会の承認（承認 番号 25059）と全被験者からの研究参加の同意を得て実 施した。被験者は運動器疾患ならびに中枢神経疾患の既 往のない健常な成人若年者 30 名（全例男性, 平均年齢 23.9 歳, 平均身長 $169.5 \mathrm{~cm}$, 平均体重 $65.5 \mathrm{~kg}$ ) とした。 対象者の膝伸展位股関節屈曲角度 (SLR) は $68.9 \pm$ 10.1 度, 指床間距離 $(\mathrm{FFD})$ は $0.0 \pm 11.8 \mathrm{~cm}$ であった (いずれも平均士標準偏差)。ヘルシンキ宣言に則り, 計 測において十分な配慮を行い, 被験者の安全に細心の注 意を払った。

\section{2. 方法}

課題は先行研究 13) と同様に体位を立位と座位の 2 水 準として，いずれも両上肢自然下垂位で肩幅程度開脚し た裸足の状態から脱力することなく, 頭頸部と体幹を可 能な限り一直線上とした状態のまま, 股関節で体幹を傾 斜して体幹前傾位を保持する運動とした（図 1)。運動 課題中の視線は頭頸部を屈曲しないように, そのまま 真っ直ぐに壁から床面をみて，視野の上や下をみること なく視野の中央に意識して視線をおくように指示した。 体幹前傾位の角度は先行研究 13) と同様に肩峰と腸骨稜 頂点を結ぶ線と床への垂直線がなす角度をゴニオメー ターで計測し，これを体幹傾斜角と定義した。体幹傾斜 角は $0,10,20,30,40,50,60^{\circ}$, 最大前傾位の 8 水 準の角度を設定した。運動課題はランダムに行わせ，そ れぞれ 30 秒間実施させた。各角度保持の間には 30 秒間 各体位の間には 5 分間の休息を設けた。また仙骨後面と 水平面前方がなす角度, つまり骨盤後傾位ほど数值が増 加する角度を仙骨傾斜角, 大転子と外側上顆を結ぶ線と 水平面前方がなす角度を大腿傾斜角と定義し, 立位と座 位での仙骨傾斜角, 立位での大腿傾斜角をデジタル傾斜 計（DI-100M，コンパクトデジタル水平器, KOD, 精 密度：平面に対し \pm 0.1 度）で計測した。

運動課題中の筋活動の測定には表面筋電計（Tele Myo G2, EM-601, Noraxon 社) を用いた。胸部脊柱起立筋, 腰部脊柱起立筋, 腰部多裂筋, 大殿筋, 大腿二頭筋を導 出筋とした。胸部脊柱起立筋は第 12 胸椎棘突起の外側
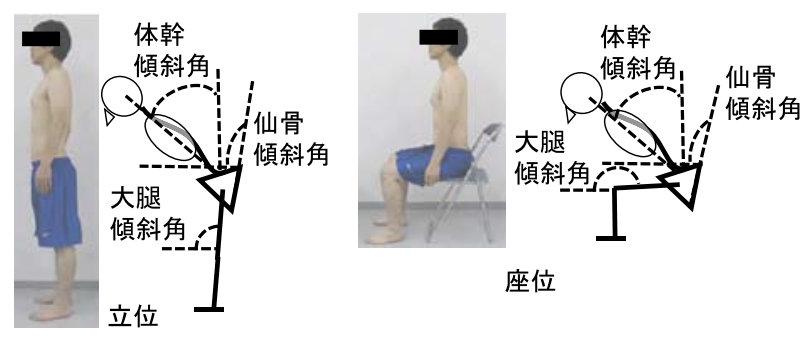

図1姿勢と運動課題 
およそ 2 から $3 \mathrm{~cm}$ の筋腹で線維走行に沿った部位, 腰 部脊柱起立筋は第 3 腰椎棘突起の外側およそ 2 から $3 \mathrm{~cm}$ の筋腹で線維走行に沿った部位, 多裂筋は第 5 腰 椎および第 1 仙椎レベルの棘突起すぐ外側で線維走行に 沿った部位，大殿筋は大転子と仙骨を結ぶ線の $1 / 2$ あた りの筋腹で走行に沿った部位，大腿二頭筋は膝関節後方 と大転子を結ぶ線の遠位 $2 / 3$ あたりの筋腹, 走行に沿っ た部位に電極を設置した ${ }^{14)}$ ，測定側は全て左とした。 導出方法は双極導出法とした。電極は銀, 塩化銀型 disposable 生体用表面電極 (Blue sensor, MEDICOTEST $\mathrm{A} / \mathrm{S}$ ）を用い, その中心間隔を $30 \mathrm{~mm}$, 皮膚インピーダ ンスを $5 \mathrm{k} \Omega$ 以内とした後, 各筋の筋線維走行に並行に 貼付した。 測定は筋電計内蔵のインピーダンステストを クリアしたことを確認後行った，表面筋電計から測定さ れたデータをサンプリング周波数 $1 \mathrm{kHz}$ で A/D 変換し, 解析用パーソナルコンピュータ（LATITUDE D800, EM-P3, Dell Computer Corporation 社) に取り込んだ. 波形は筋電解析ソフトウェア（MyoResearch Master, EM-129M, Noraxon 社) にて $10 \sim 500 \mathrm{~Hz}$ のバンドパ
スフィルターにより解析した。波形解析は生波形を心電 四ノイズ低減，全波整流，スムージングをし，筋電図積 分值（integrated electromyography；以下, IEMG）を求 めた。各角度と体位での筋活動量を最大随意収縮ではば らつきが生じうる点と, 胸部と腰部の筋活動量を把握す るために, 徒手筋力検査で判定 5 となる運動を 3 回行わ せたうちの最大值を示した際の筋活動量で除した％ MMTにて求めた。いずれも筋活動が安定した時点の前 後 0.5 秒間での IEMG を求めた.

得られたデー夕について, 角度別の比較では Friedman 検定後に多重比較検定として Holm 検定, 体 位別の比較では Wilcoxon 検定を用いた。仙骨傾斜角と 大腿傾斜角は変動係数を算出した。すべての統計学的検 討は統計ソフト R（version2.8.1）を用いて行い，いず れの統計処理も有意水準は 5\%未満とした。

\section{III. 結 果}

体位別の筋活動量を表 1 に示す。下肢筋群である大殿

表 1 体位別の筋活動量（\% MMT）

\begin{tabular}{|c|c|c|c|c|c|c|c|c|c|c|}
\hline & & & $0^{\circ}$ & $10^{\circ}$ & $20^{\circ}$ & $30^{\circ}$ & $40^{\circ}$ & $50^{\circ}$ & $60^{\circ}$ & 最大前傾位 \\
\hline \multirow[t]{5}{*}{ UES } & 立位 & 中央值 & 0.067 & 0.123 & 0.148 & 0.182 & 0.209 & 0.227 & 0.245 & 0.075 \\
\hline & & 四分位範囲 & 0.063 & 0.086 & 0.102 & 0.101 & 0.113 & 0.134 & 0.152 & 0.088 \\
\hline & 座位 & 中央值 & 0.096 & 0.135 & 0.157 & 0.181 & 0.204 & 0.209 & 0.191 & 0.145 \\
\hline & & 四分位範囲 & 0.099 & 0.100 & 0.122 & 0.121 & 0.126 & 0.134 & 0.178 & 0.115 \\
\hline & & 立位 v.s. 座位 & $*$ & & & & & $*$ & $*$ & $*$ \\
\hline \multirow[t]{5}{*}{ LES } & 立位 & 中央值 & 0.046 & 0.108 & 0.138 & 0.169 & 0.191 & 0.215 & 0.231 & 0.040 \\
\hline & & 四分位範囲 & 0.043 & 0.054 & 0.076 & 0.094 & 0.121 & 0.114 & 0.086 & 0.038 \\
\hline & 座位 & 中央值 & 0.055 & 0.088 & 0.120 & 0.151 & 0.167 & 0.181 & 0.187 & 0.060 \\
\hline & & 四分位範囲 & 0.034 & 0.065 & 0.091 & 0.086 & 0.121 & 0.151 & 0.187 & 0.065 \\
\hline & & 立位 v.s. 座位 & & & $*$ & $*$ & $*$ & $*$ & $*$ & $*$ \\
\hline \multirow[t]{5}{*}{ MF } & 立位 & 中央值 & 0.061 & 0.154 & 0.210 & 0.245 & 0.276 & 0.310 & 0.306 & 0.060 \\
\hline & & 四分位範囲 & 0.081 & 0.061 & 0.069 & 0.080 & 0.084 & 0.095 & 0.107 & 0.085 \\
\hline & 座位 & 中央値 & 0.051 & 0.104 & 0.153 & 0.191 & 0.221 & 0.237 & 0.228 & 0.055 \\
\hline & & 四分位範囲 & 0.045 & 0.064 & 0.069 & 0.098 & 0.158 & 0.237 & 0.202 & 0.078 \\
\hline & & 立位 v.s. 座位 & & $*$ & $*$ & $*$ & $*$ & $*$ & $*$ & \\
\hline \multirow[t]{5}{*}{ GMa } & 立位 & 中央值 & 0.015 & 0.023 & 0.035 & 0.053 & 0.071 & 0.074 & 0.070 & 0.070 \\
\hline & & 四分位範囲 & 0.033 & 0.050 & 0.065 & 0.084 & 0.063 & 0.058 & 0.065 & 0.065 \\
\hline & 座位 & 中央値 & 0.013 & 0.013 & 0.013 & 0.013 & 0.014 & 0.017 & 0.016 & 0.015 \\
\hline & & 四分位範囲 & 0.009 & 0.010 & 0.009 & 0.010 & 0.013 & 0.018 & 0.021 & 0.020 \\
\hline & & 立位 v.s. 座位 & $*$ & $*$ & $*$ & $*$ & $*$ & $*$ & $*$ & $*$ \\
\hline \multirow[t]{5}{*}{$\mathrm{BF}$} & 立位 & 中央値 & 0.050 & 0.118 & 0.200 & 0.217 & 0.250 & 0.283 & 0.271 & 0.200 \\
\hline & & 四分位範囲 & 0.052 & 0.129 & 0.179 & 0.208 & 0.231 & 0.250 & 0.262 & 0.318 \\
\hline & 座位 & 中央値 & 0.022 & 0.024 & 0.029 & 0.036 & 0.051 & 0.072 & 0.066 & 0.050 \\
\hline & & 四分位範囲 & 0.017 & 0.017 & 0.029 & 0.049 & 0.069 & 0.089 & 0.077 & 0.078 \\
\hline & & 立位 v.s. 座位 & $*$ & $*$ & $*$ & $*$ & $*$ & $*$ & $*$ & $*$ \\
\hline
\end{tabular}

UES: 胸部脊柱起立筋, LES: 腰部脊柱起立筋, MF: 腰部多裂筋, GMa: 大殿筋, BF: 大腿二頭筋 数值は $1.000: 100 \%$ である. *:p $<0.05$. 
筋と大腿二頭筋では，座位と比較して立位での筋活動量 がどの体幹傾斜角でも有意に高かった。しかし，大殿筋 の筋活動量は％MMT としては低值であった，体幹筋群 である多裂筋と腰部脊柱起立筋では体幹が前傾 $20^{\circ}$ の段 階ですでに立位と比較して座位での筋活動量が低值と なったが, 胸部脊柱起立筋では 10 から $40^{\circ}$ の体幹傾斜 角で立位と座位に有意差は認められなかった。

体幹傾斜角の角度別筋活動量比較時の Holm 検定の結 果, 立位では体幹傾斜角の増加に伴う筋活動量の増大が 認められたが, 胸部脊柱起立筋, 腰部脊柱起立筋, 多裂 筋では $50^{\circ}$ と $60^{\circ}$ 間, 大殿筋と大腿二頭筋では $40^{\circ}$ 以降 で有意差が認められなかった。一方, 座位では体幹傾斜 角の増加に伴う筋活動量の増大が大殿筋以外のすべてで 認められたが, 胸部脊柱起立筋と腰部脊柱起立筋では $40 \sim 60^{\circ}$, 多裂筋では $30 \sim 60^{\circ}$, 大腿二頭筋では $40^{\circ}$ 以 降で有意差が認められなかった，体幹傾斜角が最大前傾 位に打ける筋活動量は, 胸部脊柱起立筋では立位で 0 , $10^{\circ}$, 座位では 0 から $40^{\circ}$ の筋活動量と比較して有意差 が認められなかった。腰部脊柱起立筋と多裂筋では最大 前傾位での筋活動量は立位で $0^{\circ}$, 座位で $0,10^{\circ}$ での筋 活動量と有意差が認められなかった。逆に大殿筋では最 大前傾位での筋活動量は, 立位で $20^{\circ}$ 以降, 座位ですべ ての前傾位での筋活動量と有意差が認められなかった。 大腿二頭筋は立位で $20^{\circ}$ 以降, 座位で $40^{\circ}$ 以降での筋活 動量と有意差が認められなかった。

体位と体幹傾斜角別の仙骨傾斜角, 大腿傾斜角を表 2 に示す。仙骨傾斜角の変動係数は立位で平均 $19.2 \%$, 座位で平均 $15.8 \%$, 大腿傾斜角の変動係数は立位で平 均 $6.0 \%$ であった。最大前傾位の体幹傾斜角は立位で $108.9 \pm 22.3^{\circ}$, 座位で $84.7 \pm 10.1^{\circ}$ であった。

\section{IV. 考 察}

屈曲驰緩現象について Callagham ら 15) は座位での出 現角度が立位の半分の前傾角度の段階と報告している. だがGeisserら 12) が指摘しているように動作速度や屈 曲弛緩現象出現の定義など方法によって結果の具体的な 数值は不一致となりうる，筋電図以外の知見としては筋 圧の検討 16$)$ があり, ある一定の前傾角度からは筋圧が 一定值をとるとされ，脊柱の支持機構が筋系から靶帯系 に移行したものとされる. 今回, 姿勢保持がより前傾位 となるにつれ, 胸・腰部脊柱起立筋と多裂筋の筋活動量 は増加したが，立位ではこれらの筋が $50^{\circ}$ と $60^{\circ}$, 座位 では胸・腰部脊柱起立筋が $40^{\circ}$ から $60^{\circ}$, 多裂筋が $30^{\circ}$ から $60^{\circ}$ で筋活動量が有意に増加しない結果となった。 これは筋圧の報告と同様に立位と比較して座位では早期 に筋系から勒帯系へ支持機構が移行した可能性が考えら れた。 これは Callagham ら ${ }^{15)}$ の報告を支持するものと 思われる，しかし，本研究の結果のみではCallagham ら 15)が述べている勒带系への移行は不明である。多裂 筋については骨盤に付着する筋であるため, 体幹を前傾 した際には下肢と連結する骨盤帯を制御するための筋活 動が立位では必要となる。それに対して，座位で体幹を 前傾した際は下肢の影響が少なくなる。 そのため, 浅い 前傾角度の段階で立位以上の筋活動がなくても体幹を支 持できる状態が作られていたと考えられる。つまり座位 で体幹を前傾させた場合は, 立位時よりも腰背部でバラ ンスをとる必要性が軽減されるため, 腰背部の筋活動に よる伸展作用が早期に一定になったと考える. 最大前傾 位での体幹傾斜角はばらつきが特に立位で大きかった。 また，筋活動量のばらつきとしても立位での大腿二頭筋 の四分位範囲が大きかった，立位での胸・腰部脊柱起立

表 2 体位と体幹傾斜角別の仙骨傾斜角, 大腿傾斜角

\begin{tabular}{|c|c|c|c|c|c|c|c|c|c|c|c|c|c|c|c|c|}
\hline \multicolumn{17}{|c|}{ 仙骨傾斜角 } \\
\hline 体位 & \multicolumn{8}{|c|}{ 座位 } & \multicolumn{8}{|c|}{ 立位 } \\
\hline 体幹傾斜角 & $0^{\circ}$ & $10^{\circ}$ & $20^{\circ}$ & $30^{\circ}$ & $40^{\circ}$ & $50^{\circ}$ & $60^{\circ}$ & $\begin{array}{c}\text { 最大 } \\
\text { 前傾位 }\end{array}$ & $0^{\circ}$ & $10^{\circ}$ & $20^{\circ}$ & $30^{\circ}$ & $40^{\circ}$ & $50^{\circ}$ & $60^{\circ}$ & $\begin{array}{c}\text { 最大 } \\
\text { 前傾位 }\end{array}$ \\
\hline 平均（度） & 87.8 & 80.7 & 74.4 & 69.5 & 65.2 & 61.4 & 57.9 & 48.4 & 74.6 & 67.1 & 61.4 & 56.3 & 51.8 & 47.6 & 44.7 & 28.3 \\
\hline 標準偏差（度） & 7.1 & 8.8 & 9.6 & 10.1 & 11.0 & 11.7 & 11.7 & 11.5 & 7.5 & 7.2 & 7.6 & 8.9 & 9.4 & 10.3 & 11.3 & 11.2 \\
\hline 変動係数（\%） & 8.1 & 10.9 & 12.9 & 14.5 & 16.9 & 19.0 & 20.1 & 23.7 & 10.0 & 10.7 & 12.4 & 15.8 & 18.2 & 21.7 & 25.2 & 39.6 \\
\hline \multicolumn{9}{|c|}{ 大腿傾斜角 } & & & & & & & & \\
\hline 体位 & \multicolumn{8}{|c|}{ 立位 } & & & & & & & & \\
\hline 体幹傾斜角 & $0^{\circ}$ & $10^{\circ}$ & $20^{\circ}$ & $30^{\circ}$ & $40^{\circ}$ & $50^{\circ}$ & $60^{\circ}$ & $\begin{array}{c}\text { 最大 } \\
\text { 前傾位 }\end{array}$ & & & & & & & & \\
\hline 平均（度） & 85.5 & 85.5 & 86.5 & 88.1 & 89.7 & 91.1 & 92.1 & 94.6 & & & & & & & & \\
\hline 標準偏差（度） & 5.2 & 5.6 & 5.8 & 5.5 & 5.3 & 4.9 & 4.9 & 5.8 & & & & & & & & \\
\hline 変動係数（\%） & 6.1 & 6.5 & 6.7 & 6.2 & 5.9 & 5.4 & 5.3 & 6.2 & & & & & & & & \\
\hline
\end{tabular}


筋, 多裂筋の最大前傾位での筋活動量は 0 度での筋活動 量と有意差が認められなかった。体幹筋群はFRPが最 大前傾位の前段階に出現していたため, 体幹傾斜角の最 大前傾位の角度の個人差による筋活動量の違いの影響が 立位も座位も少なかったと考える。逆に大殿筋と大腿二 頭筋の最大前傾位での筋活動量は 0 度の筋活動量と有意 差が認められ, 特に立位での体幹最大前傾位での大腿二 頭筋の筋活動量は 0 度での值と比較して高值を示した。 これは体幹最大前傾位での大腿傾斜角の結果からも, 立 位での体幹前傾位保持において支持基底面に対する重心 線の位置関係を適切に保つために慰部が後方へ移動した ことに対する制御として筋活動が高まったものと考え る.そして, その際に SLR, FFDの標準偏差の結果と してもあらわされている個人の柔軟性の差異が立位での 大腿二頭筋の最大前傾位での筋活動量の四分位範囲の大 きさとしても生じていたと思われる。

以上のことから, 座位では立位と比較して, より体幹 前傾角度が浅い段階, 胸・腰部脊柱起立筋では 40 度, 多裂筋では 30 度の段階から運動単位としての筋活動つ まり活動張力よりも筋の静止張力や勒帯性の支持機構が 働いている可能性が考えられた。本結果は健常者を対象 とした筋電図学的検討の結果である。よって, 体幹前傾 において背筋群の過活動によって FRP が出現しない腰 痛症においては, 座位では立位よりも浅い前傾位で背筋 群を弛緩させるべきである。具体的にはバルーンなどを 腹部に抱え込ませた座位の前傾位でバルーンにもたれる ように脱力させるなどの手法が考えられる。逆に筋活動 が弱化している腰痛症においては, 立位では座位よりも 深い前傾位まで背筋群の筋活動を賦活させて脊柱安定化 をはかるべきであることが示唆された。 また, 本研究で 得た知見は座位では浅い角度の段階で筋活動での制御が 行われていないともいえる。そのため, 座位では立位と 比較して浅い体幹前傾角度の段階で不意の外力などが加 わると腰部の支持性が破綻しやすく，腰痛を引き起こす 可能性があることも示唆するものと考える.

しかし, 本研究の限界としては, 対象者のSLRと FFD の值のばらつきや仙骨傾斜角の変動係数が高かっ たことから，たとえ静的姿勢であっても腰椎骨盤リズム の個人差がある程度存在した点である。運動条件である 多段階の体幹傾斜角の保持を体幹と大腿の中間に存在す る骨盤で調整したため, 坐骨結節に付着するハムストリ ングスの柔軟性の個人差が仙骨の動きに影響した可能性 が考えられた。この点が今後の検討課題である.
謝辞 本研究はJSPS 科研費 25882026 の助成を受けた ものである。

\section{引用文献}

1) 厚生労働省大臣官房統計情報部：グラフで見る世帯状況一 国民生活基礎調查 (平成 22 年) の結果から一、統計印刷工業, 東京, 2012, pp28-41.

2) 藤本一美 : 高齢者福祉の諸問題一介護者の腰痛. 老年医学, 2005, 43(9): 1435-1440.

3) 熊谷信二, 田井中秀嗣, 宮島啓子 - 他 : 高齢者介護施設 に扮ける介護労働者の腰部負担. 産衛誌, 2005, 47(4): 131-138.

4) Floyd WF, Silver PH: The function of the erectores spinae muscles in certain movements and postures in man. J Physiol, 1951, 129(1): 184-203.

5) Holleran K, Pope M, Haugh L, et al: The response of the flexion-relaxation phenomenon in the low back to loading. Iowa Orthop J, 1995, 15: 24-28.

6) Shirado O, Ito T, Kaneda K, et al: Flexion-relaxation phenomenon in the back muscles. A comparative study between healthy subjects and patients with chronic low-back pain. Am J Phys Med Rehabil, 1995, 74(2): 139-144.

7) Triano JJ, Schultz AB: Correlation of objective measure of trunk motion and muscle function with low back disability ratings. Spine, 1987, 12(6): 561-565.

8) 菊地臣一：腰痛. 医学書院, 東京, 2003, pp43-62.

9) Geisser ME, Ranavaya M, Haig AJ, et al: A Meta-Analytic Review of Surface Electromyography Among Persons With Low Back Pain and Normal, Healthy Controls. J Pain, 2005, 6(11): 711-726.

10) Mayer TG, Neblett R, Brede E, et al: The Quantified Lumbar Flexion-Relaxation Phenomenon Is a Useful Measurement of Improvement in a Functional Restoration Program. Spine, 2009, 34(22): 2458-2465.

11) Dankaerts W, O'Sullivan P, Burnett A, et al: Altered Patterns of Superficial Trunk Muscle Activation During Sitting in Nonspecific Chronin Low Back Pain Patient. Spine, 2006, 31(17): 2017-2023.

12) Geisser ME:Surface Electromyography and Low Back Pain. Biofeedback, 2007, 35(1), 13-16.

13) 隈元庸夫, 世古俊明, 田中昌史 - 他：立位と座位にお ける屈曲弛緩現象の違い. 理学療法科学, 2014, 29(4): 321-626.

14) 下野俊哉：表面筋電図マニュアル。酒井医療, 東京, 2010 , pp123-159.

15) Callaghan JP, Dunk NM: Examination of the flexion relaxation phenomenon in erector spinae muscles durung short duration slumped sitting. Clin Biomech, 2002, 17(5): 353-360.

16) 紺野慎一, 菊地臣一：腰椎背筋群のコンパートメント内圧 上昇と腰痛. 臨整外，1993，28(4): 419-426. 